\title{
Kernicterus Related to Isoimmunization
}

National Cancer Institute

\section{Source}

National Cancer Institute. Kernicterus Related to Isoimmunization. NCI Thesaurus. Code C101270.

Encephalopathy in infants due to high levels of unconjug ated bilirubin that are a result of $\mathrm{Rh}$ incompatibility between the mother and the fetus. 